ROCZNIKI TEOLOGICZNE

Tom LXVII, zeszyt $10-2020$

DOI: http://dx.doi.org/10.18290/rt206710-6

BOGDAN KULIK MSF

\title{
APOSTOLSTWO DOBREJ ŚMIERCI - HISTORIA I MISJA
}

\author{
APOSTOLATE OF GOOD DEATH - HISTORY AND MISSION
}

\begin{abstract}
On July 22, 1908, Pope Pius X established the Association of Our Lady of a Happy Death as universal for the whole Church. On May 30, 1987, the Primate of Poland, Cardinal Joseph Glemp, approved the Polish Branch of the Association at the Shrine to the Virgin Mary in Górka Klasztorna. He also permitted the Missionaries of the Holy Family to carry out this work. The purpose of the Association is the propagation of prayer and preparation for a good death. The article presents in details history and mission of the Association, also called the Apostolate of Good Death.
\end{abstract}

Key words: to accompany; good death; apostolate.

„Kościół od zawsze umie towarzyszyć chorym. Iluż księży, zakonników i zakonnic spędziło długie godziny przy ludziach będących u kresu życia? $\mathrm{Na}$ końcu ziemskiej drogi ludzie nie potrzebują zimnej strzykawki, która zadaje śmierć. Potrzebują współczującej dłoni. [...] Umrzeć godnie znaczy umrzeć, będąc kochanym! Wszystko inne jest kłamstwem! Dobrze o tym wiedzą osoby, które z niestrudzoną ofiarnością oddają się służbie na oddziałach opieki paliatywnej, by umniejszać ból, towarzyszyć w samotności i kochać ludzi: niezwykle rzadko się zdarza, żeby chory zażądał eutanazji. Jeśli to czyni, jego prośba skrywa udrękę. W gruncie rzeczy uważam, że jeśli eutanazja jest dzisiaj przedmiotem debat, to dlatego, że my, zdrowi i sprawni, nie możemy znieść obecności chorych i cierpiących. Oni żebrzą o naszą miłość i współczucie. Nie mamy odwagi zmierzyć się z ich spojrzeniem. Nie mamy już dość miłości do ofiarowania. [...] Odpowiedzią na eutanazję jest miłość aż po śmierć!"”.

Ks. dr Bogdan KULIK MSF - Wydział Teologiczny, Uniwersytet im. Adama Mickiewicza w Poznaniu; adres do korespondecnji: ul. Wieżowa 2/4, 61-111 Poznań; e-mail: kulikbogdan@op.pl; ORCID: https://orcid.org/0000-0002-8627-3821.

${ }^{1}$ R. SARAh, N. DiAT, Wieczór się zbliża i dzień już się chyli, przeł. A. Kuryś, Wydawnictwo Sióstr Loretanek, Warszawa 2019, s. 250-252. 
Te przeszywające serce słowa odnajdujemy w książce kard. Roberta Saraha, w której z odwagą proroka próbuje On opisać rzeczywistość współczesnego Zachodu. Autor nie zostawia cienia wątpliwości co do tego, że towarzyszenie z miłością jest postawą, której człowiek potrzebuje na wszystkich etapach swojego życia.

Każdy pragnie towarzyszącej miłości w czasie choroby i podczas procesu umierania, ale nie tylko. Kardynał zaznacza, że „człowiek Zachodu czuje paniczny lęk na myśl o własnym cierpieniu i śmierci"2. Czyż ten lęk nie jest przerażającą formą cierpienia, która rozpoczyna niszczenie ludzi kiedy jeszcze są zdrowi i w pełni sił? Zatem także na tym etapie, gdy jeszcze nie ma żadnej zatrważającej diagnozy lekarskiej czy symptomów wskazujących na rychły koniec życia, ludziom trzeba towarzyszyć z miłością, uwalniając ich od lęku poprzez ogłaszanie im prawdy o sensie cierpienia i śmierci. To właśnie czyni Kościół głosząc Ewangelię o Chrystusie, „który przezwyciężył śmierć, a na życie i nieśmiertelność rzucił światło przez Ewangelię” (2 Tm 1,10).

Kard. Sarah, tłumacząc przyczyny ekspansji eutanazji, przypomina: „Kościół jest ostatnim szańcem obronnym przed makabryczną i samobójczą nową globalną etyką. Musi oświecić wszystkie sumienia. Kiedy słońce Kościoła się schowa, ludziom jest zimno"3.

Jednym ze sposobów, w jaki Kościół towarzyszy ludziom na wszystkich etapach ich zmagania z lękiem przed śmiercią, jest posługa podejmowana przez świeckich i duchownych członków Apostolstwa Dobrej Śmierci, którego prezentacja jest celem niniejszego artykułu.

Historia powstania Apostolstwa Dobrej Śmierci (ADS lub ADŚ) ${ }^{4}$, którego pełna oficjalna nazwa brzmi: Stowarzyszenie Matki Bożej Patronki Dobrej Śmierci ${ }^{5}$, wpisuje się w kult Matki Bożej Bolesnej sięgający swymi korzeniami faktów opisanych w Ewangeliach. W sposób szczególny podkreśla się dwa z nich: proroctwo Symeona skierowane do Matki Jezusa: „Twoją duszę miecz przeniknie" (Łk 2,35) i obecność Maryi przy Jezusie w chwili Jego śmierci na krzyżu (por. J 19,25-27). Te wydarzenia legły u podstaw obecnej w chrześcijaństwie czci dla współcierpiącej Matki Pana, która na przestrzeni wieków rozwijała się, przyjmując wielorakie formy wyrazu w liturgii, sztuce

\footnotetext{
${ }^{2}$ Tamże, s. 250

${ }^{3}$ Tamże, s. 253.

${ }^{4} \mathrm{~W}$ statucie francuskim czytamy: „L'Association de Notre-Dame de la Bonne Mort, appelée aussi par les Souverains Pontifes "Apostolat de la Bonne Mort»" (J.-C. Boulanger, List do ks. Prowincjała Polskiej Prowincji Misjonarzy Świętej Rodziny ks. Włodzimierza Burzawy MSF, Sées 24.11.2004).

${ }^{5} \mathrm{~W}$ artykule nazwy będą używane zamiennie.
} 
jak i w nowych sposobach życia (np. bractwa i wspólnoty zakonne powstałe w celu szerzenia nabożeństwa do Matki Bożej Bolesnej) $)^{6}$.

\section{HISTORIA APOSTOLSTWA WE FRANCJI}

W ten wielowiekowy nurt pobożności maryjnej włączyli się kapłani z francuskiej wspólnoty Ojców Najświętszej Maryi Panny (Institut de Prêtres de Sainte-Marie de Tinchebray) ${ }^{7}$, którzy postanowili w prowadzonym przez nich sanktuarium w Tinchebray (Normandia, Francja) powołać do życia nowe stowarzyszenie. Stało się to na mocy decyzji ordynariusza diecezji Sées, bpa Charlesa Frederica Rousseleta, w kościele Matki Bożej w Tinchebray, dnia 14 maja 1865 roku. Biskup dokonał kanonicznej erekcji Stowarzyszenia Dobrej Śmierci pod tytułem i wezwaniem „Jezusa umierającego na Krzyżu i Najświętszej Maryi Panny uczestniczącej w Jego Boleściach"8. Akt ten został potwierdzony w pierwszym statucie, w którym zostały określone: cele, praktyki, warunki przynależności, zobowiązania i regulamin szczegółowy9

Dzieło to powstało jako filia Arcybractwa Dobrej Śmierci założonego w Rzymie w 1648 roku przez o. Wincentego Caraffa SJ przy kościele Il Gesù pod nazwą „Jezusa Chrystusa umierającego na Krzyżu i Najświętszej Maryi Panny”, popularnie nazywanego „Stowarzyszeniem Dobrej Śmierci”. Jako filia Stowarzyszenie, założone przez ojców z Tinchebray, miało na początku

\footnotetext{
${ }^{6} \mathrm{Na}$ temat historii i teologii kultu Matki Bożej Bolesnej por. np.: Association de Notre-Dame de la Bonne-Mort. Notice Historique, Tinchebray 1963, s. 2-9; J. WoJTKOWSKI, Bolesna Matka Boża, I. Kult, Koronka, w: Encyklopedia Katolicka, t. 2, red. F. Gryglewicz, R. Łukaszyk, Z. Sułowski, Towarzystwo Naukowe KUL, Lublin 1976, k. 754-757; J. MoRICOVÁ, Matka Boża Siedmiobolesna - patronka Stowacji. Teologia i kult, (Mariologia w kontekście, t. 3), Redakcja Wydawnictw KUL, Lublin 2002; Kongregacja DS. Kultu Bożego i DysCypliny SAKRAmentów, Dyrektorium o pobożności ludowej i liturgii. Zasady i wskazania, Pallottinum, Poznań 2003, nr 136-137, 145, 147; M.M. Muraro, M.M. Pedico, Addolorata, w: Mariologia, red. S. De Fiores, V. Ferrar Schiefer, S.M. Perrella, San Paolo, Cinisello Balsamo (Milano) 2009, s. 6-16; A. SERRA, Maria presso la Croce. Solo l'Addolorata? Verso una rilettura dei contenuti di Giovanni 19,25-27, (Edizione Messaggero Padova, t. 12. Maria nella tradizione biblica 3/2), Messaggero di Sant'Antonio, Padova 2011; K. MoszumańsKi, Sanktuaria Matki Bożej Bolesnej w diecezji świdnickiej, w: Misericordia et veritas. Księga jubileuszowa dla uczczenia biskupa Ignacego Deca, t. 2: $W$ darze, red. A. Tomko, PWT, Wrocław 2014, s. 433-452; M.M. Pedico, El culto de la Virgen de los Dolores desde 1848 a 1950 en la Orden de los Siervos de Maria, b.m.r.w.; wydanie internetowe: http://servidimaria.net/sitoosm/es/historia/conguno/11.pdf (08.08.2019).

${ }^{7}$ Por. F.J. PrÉvoteau, Les Frères de Tinchebray (1850-1882), b.m., 2007; wydanie internetowe: http://www.lamennais.org/wp-content/uploads/2016/03/em36.pdf (06.09.2019).

${ }^{8}$ Association de Notre-Dame de la Bonne-Mort, s. 14.

${ }^{9}$ Treść statutu por. tamże, s. 14-15.
} 
jedynie charakter dzieła o zasięgu lokalnym i diecezjalnym ${ }^{10}$. Jednak ten stan rzeczy wkrótce uległ zmianie.

Z powodu przemian politycznych we Francji i ustaw prowadzących do laicyzacji państwa uchwalonych w 1901 i 1905 roku ojcowie prowadzący Stowarzyszenie byli zmuszeni do opuszczenia sanktuarium i siedziby Stowarzyszenia w Tinchebray. Część z nich została aresztowana, a część wyjechała do Rzymu ${ }^{11}$. Tam za zgodą Stolicy Apostolskiej reskryptem z dnia 17 maja 1905 roku siedziba Stowarzyszenia Matki Bożej Patronki Dobrej Śmierci została przeniesiona do Rzymu ${ }^{12}$. Niedługo potem, na prośbę o. Rondeta - ówczesnego dyrektora Stowarzyszenia - papież Pius X w reskrypcie z dnia 22 lipca 1908 roku nadał Stowarzyszeniu niezależność i charakter ogólnokościelny (uniwersalny) ${ }^{13}$. W reskrypcie oprócz decyzji o przyznaniu odpustów nowemu dziełu czytamy, że papież wyraża zgodę, ,aby w miejsce starego Bractwa Dobrej Śmierci utworzonego w macierzystym domu Ojców Najświętszej Maryi Panny w Tinchebray, zostało utworzone nowe stowarzyszenie pod nazwą Stowarzyszenie Matki Boskiej Patronki Dobrej Śmierci”"14.

Ze względu na to, że o. Rondet doprowadził do przekształcenia filii bractwa przy kościele Il Gesù w stowarzyszanie powszechne (uniwersalne) dla całego Kościoła, zyskał miano prawdziwego założyciela Stowarzyszenia Matki Bożej Patronki Dobrej Śmierci ${ }^{15}$.

Aby uzupełnić obraz historycznego rozwoju Stowarzyszenia do tego momentu oraz ukazać jego znaczenie i rangę, nie wolno zapomnieć, że Apostolstwo było polecane przez trzech kolejnych papieży. Swoją aprobatę dla tego dzieła $\mathrm{w}$ oficjalnych dokumentach wyrazili: Pius $\mathrm{X}^{16}$, Benedykt $\mathrm{XV}^{17}$

\footnotetext{
10 Tamże, s. 18-20, 26.

${ }^{11}$ Por. tamże, s. 25. Na temat ówczesnej sytuacji Kościoła we Francji por. np. A.J. SoBCzYK, P.J. KRUPA, W kręgu duchowości świętorodzinnej, Bernardinum, Pelplin 2007, s. 54-66.

12 Por. Association de Notre-Dame de la Bonne-Mort, s. 25.

${ }^{13}$ Kopia rękopisu reskryptu znajduje się w archiwum ADS w Górce Klasztornej. Tłumaczenie na j. francuski reskryptu por. Association de Notre-Dame de la Bonne-Mort, s. 26-28. Skrócone tłumaczenie na j. polski por. Stowarzyszenie Matki Boskiej Patronki Dobrej Śmierci, Bernardinum, Górka Klasztorna 1996, s. 33-34.

${ }^{14}$ Association de Notre-Dame de la Bonne-Mort, s. 26. Należy przypomnieć, że wykaz odpustów został zweryfikowany i zmieniony po Soborze Watykańskim II, por. Stowarzyszenie Matki Boskiej, s. 34.

${ }^{15}$ Por. Association de Notre-Dame de la Bonne-Mort, s. 29.

${ }^{16}$ Pius X, List Ubere cum fructu, Rzym 30.04.1911, (AAS 3, 265-266), wydanie internetowe: http://www.vatican.va/archive/aas/documents/AAS-03-1911-ocr.pdf (28.11.2019).

${ }^{17}$ Benedykt XV, List Peraccepta Nobis, Rzym 24.11.1914 (AAS 6,693); wydanie internetowe: http://www.vatican.va/archive/aas/documents/AAS-06-1914-ocr.pdf (28.11.2019); TENŻE, List apostolski Inter sodalicia, Rzym 31.05.1921, (AAS 18,181-185); wydanie internetowe: http://
} 
i Pius $\mathrm{XI}^{18}$. Warto zacytować przynajmniej jeden fragment wypowiedzi papieskiej, a mianowicie następujące słowa Piusa XI:

„Na wieczną rzeczy pamiątkę jest postanowione, że Kapłani od Świętej Marii, potocznie de Tinchebray, zakładają stowarzyszenie Naszej Pani od Dobrej Śmierci, ufundowane w celu - którego to zarówno nadzwyczajność jak i szczególność dwaj ostatni nasi poprzednicy rozpoznali i potwierdzili aby przez to stowarzyszenie, któremu przewodzą, do wiecznego zbawienia wszystkich umierających się przyczyniali. Jest rzeczą wiadomą, że tego rodzaju apostolat, zwany od dobrej śmierci, od którego żaden w tych czasach nie wydaje się bardziej owocny i zbawienny, przez tych Prezbiterów wspaniałomyślnie jest prowadzony, skoro wspomniane stowarzyszenie jest dynamicznie i szeroko po świecie propagowane. I stąd faktem jest, że za sprawą Dziewicy Bolesnej, boskiej jego Patronki, Orędowniczki, liczni wierni trwają w obyczajach chrześcijańskiego życia, inni zaś liczni uzyskali dla siebie dobre owoce i święcie w Panu odeszli. Ponieważ w powiększaniu tego dzieła nie tylko można widzieć pewien szczególny plan Boga, który chce, by wszyscy ludzie byli zbawieni, wobec tego my sami powinniśmy słusznie radować się, my którzy z tej wysokości najwyższego papiestwa nie szukamy niczego innego, jak tylko wiecznego zbawienia dusz, które Chrystus odkupił krwią swoją. Dlatego nie tylko chcemy, by Prezbiterzy od Świętej Marii dokładnie wykonywali powierzony im mandat niczym własny, lecz także by kapłani i świeccy, którzy noszą miano zelatorów, wypełniali obowiązki stowarzyszenia wobec innych, by wytrwale, dla osiągnięcia łaski świętego trwania w Bogu przez jak najliczniejszych, z największym wysiłkiem i modlitwą pomagali tymże kapłanom jako współuczestnicy w trudzie oraz ich towarzysze. Jeśli rzeczywiście to uczynią, z pewnością nie tylko wypełnią to, co odpowiada chrześcijańskim obowiązkom, lecz także co w najwyższym stopniu godne chrześcijańskiej miłości”" ${ }^{19}$.

www.vatican.va/archive/aas/documents/AAS-10-1918-ocr.pdf (28.11.2019); TENŻE, List apostolski Sodalitatem, Rzym 31.05.19921, (AAS 13,342-346); wydanie internetowe: http://www. vatican.va/archive/aas/documents/AAS-13-1921-ocr.pdf (28.11.2019).

${ }^{18}$ PIUS XI, List apostolski Explorata res, Rzym 02.02.1923, (AAS 15,103-107), wydanie internetowe: http://www.vatican.va/archive/aas/documents/AAS-15-1923-ocr.pdf (28.11.2019). Do tego dokumentu, jak i do Sodalitatem Benedykta XV, odwołuje się P.F. Palmer, omawiając praktykę udzielania sakramentu namaszczenia chorych; por. P.F. PALMER, The Purpose of Anointing the Sick. A Reappraisal, „Theological Studies” 1958, nr 19, s. 340-341.

19 „Ad perpetuam rei memoriam. - Explorata res est, Presbyteros a Sancta Maria, vulgo de Tinchebray, sodalitatem Nostrae Dominae a Bona Morte condidisse, ea sibi causa proposita quam proximi duo decessores Nostri tamquam peculiarem ipsorum ac propriam agnoverunt ac probarunt - ut per eandem, cui praesunt, sodalitatem aeternae morientium saluti efficaciter 
Po wybuchu II wojny światowej o. Rondet powrócił do Tinchebray. Niestety podczas działań wojennych klasztor ucierpiał a archiwum Stowarzyszenia zostało skradzione. O. Rondet zmarł wiosną $1945 \mathrm{roku}^{20}$. Po jego śmierci Stowarzyszenie rozwijało się pod opieką ojców Najświętszej Maryi Panny aż do roku 2002. Wtedy to, ówczesny dyrektor, o. Yves Douguet, poprosił ordynariusza diecezji Sées o pomoc w zapewnieniu godnej kontynuacji dzieła. Wspólnota ojców z Tinchebray z powodów personalnych (brak powołań i podeszły wiek nielicznych już współbraci) nie była w stanie dłużej kierować Stowarzyszeniem. W konsekwencji, na mocy decyzji Papieskiej Rady ds. Świeckich, Stowarzyszanie Matki Bożej Patronki Dobrej Śmierci zostało przeniesione do sanktuarium diecezjalnego diecezji Sées w Montligeon, stając się w ten sposób stowarzyszeniem diecezjalnym ${ }^{21}$.

\section{HISTORIA APOSTOLSTWA W POLSCE}

Jeśli chodzi o historię polskiej filii Apostolstwa, to rozpoczyna się ona wraz z odzyskaniem przez Polskę niepodległości w 1918 roku. Gdy po uznaniu przez Piusa X Stowarzyszenia dziełem ogólnokościelnym o. Rondet rozesłał o nim informacje do wielu krajów, dotarły one także do naszej Ojczyzny. Podaje się, że w okresie międzywojennym Stowarzyszenie działało w całym kraju, a do szczególnie gorliwych zelatorów zalicza się kapucyna o. Ignacego Zamożyca oraz Alojzego Balcera z Bydgoszczy ${ }^{22}$.

prospicerent. Constat item, eiusmodi apostolatum, ut vocant, bonae mortis, quo quidem nullus his temporibus salubrior ac fructuosior appareat, ab ipsis Presbyteris esse mirifice provectum, propagata celeriter lateque per orbem ea, quam nominavimus, sodalitate; factumque inde esse, ut, Virgine Perdolente, augusta eius Patrona, deprecatrice, plurimi numero christifideles in christianae vitae instituto perseveraverint, aliique bene multi et se ad bonam frugem receperint et sancte in Domino obierint. Cuius in amplificatione operis cum praecipuum quoddam cernere licea amantissimi Dei consilium, qui vult omnes homines salvos fieri, tum laetari Nosmet ipsi iure optimo debemus, qui ex hoc summi Pontificatus fastigio non aliud demum quaerimus nisi animarum, quas suo Christus redemit sanguine, salutem sempiternam. Itaque volumus non modo ut Presbyteri a Sancta Maria mandatum sibi officium, tamquam proprium, impense persequantur, sed etiam ut sacerdotes et laici, qui, zelatores nomine, sodalitatis negotium prae ceteris agunt, eosdem Presbyteros, ut laboris consortes et socii, summa contentione adiuvent, adhibitis omne genus industriis et precibus ad gratiam sancte monendi quam plurimis a Deo impetrandam. Quod profecto si fecerint, rem utique facturi sunt cum congruentem christianis officiis, tum christiana caritate summopere dignam" (PIUS XI) [tłum. ks. M. Gubernat MSF].

${ }^{20}$ Association de Notre-Dame de la Bonne-Mort, s. 29; Stowarzyszenie Matki Boskiej, s. 35.

${ }^{21}$ PAPIESKa RADA DS. ŚWIECKICH, Dekret N. 535/04/S-61/B, Watykan 13.03.2004.

${ }^{22}$ Stowarzyszenie Matki Boskiej, s. 38. 
Po wojnie, z powodu komunistycznych rządów, w Polsce notuje się brak czynnej działalności Apostolstwa, aż do roku 1981, w którym to ks. Jan Czekała MSF, jako pierwszy z Misjonarzy Świętej Rodziny, wysyła do Tinchebray swoje zgłoszenie do Stowarzyszenia i zostaje do niego przyjęty. Od tego momentu zainteresowanie dziełem nieustannie rośnie tak wśród współbraci ks. Czekały, jak i wśród wiernych powierzonych ich duszpasterskiej opiece ${ }^{23}$.

Aby zapewnić właściwą formację nowym członkom Stowarzyszenia, 22 marca 1982 roku, dyrektor o. Y. Dougue ustanawia zelatorem Apostolstwa na terenie Polski ks. Piotra Żelichowskiego MSF. Następnie, dzięki staraniom ks. Piotra i za zgodą przełożonych zakonów Najświętszej Maryi Panny z Tinchebray i Misjonarzy Świętej Rodziny, kardynał Józef Glemp 30 maja 1987 roku eryguje Polską Filię Stowarzyszenia, a jej prowadzenie powierza Zgromadzeniu Misjonarzy Świętej Rodziny ${ }^{24}$. Jednocześnie Stowarzyszenie zostaje uznane przez władze zakonne Zgromadzenia za jedno $\mathrm{z}$ jego dzieł apostolskich wpisanych na stałe do Dyrektorium Prowincjalnego Polskiej Prowincji MSF, w którym czytamy: „Jednym z dzieł apostolskich Prowincji jest działalność Stowarzyszenia Matki Bożej Patronki Dobrej Śmierci, zwanego Apostolstwem Dobrej Śmierci (ADS), które - wypełniając swe posłannictwo w ramach własnego statutu międzynarodowego - realizuje cele Zgromadzenia" ${ }^{25}$. Na centralę polskiej filii zostaje wyznaczone sanktuarium maryjne w Górce Klasztornej, w którym posługę duszpasterską sprawują Misjonarze Świętej Rodziny. Pierwszym dyrektorem polskiej filii Apostolstwa Dobrej Śmierci zostaje kustosz góreckiego sanktuarium, ks. Antoni Zimny MSF, który piastuje tę funkcję do 1989 roku. Kolejnymi dyrektorami byli: ks. Piotr Żelichowski MSF (1989-1996) i ks. Antoni Żebrowski MSF (1996-2015) ${ }^{26}$. Obecnie funkcję tę pełni ks. Grzegorz Górnik MSF (od 2015).

W 1993 roku władze zakonne zwróciły się do biskupów diecezjalnych w Polsce z prośbą o zezwolenia na działalność Stowarzyszenia na terenie ich diecezji. Pozytywna odpowiedz hierarchów przyczyniła się do dynamicznego rozwoju dzieła, któremu nie przeszkodziło wspominane już przeniesienie francuskiej centrali Stowarzyszenia z Tinchabray do Montligeon. W tym samym roku biskup diecezji Sées oficjalnie potwierdził status Misjonarzy

\footnotetext{
${ }^{23}$ Tamże, s. 38; por. J. CZEKA£A, Wszystko zaczęło się od wypadku... czyli początki ADS w Polsce, „Nadzieja i Życie” 2017, nr 1, s. 4-5.

${ }^{24}$ J. GLEMP, Dekret N. 2150/87/PR, Gniezno 30.05.1987.

${ }^{25}$ Dyrektorium Prowincjalne Polskiej Prowincji MSF, w: Konstytucje i Dyrektorium Generalne. Dyrektorium Prowincjalne Polskiej Prowincji, Zgromadzenie Misjonarzy Świętej Rodziny, Poznań $2002^{3}$, nr 55.

${ }^{26}$ Stowarzyszenie Matki Boskiej, s. 39-40.
} 
Świętej Rodziny Prowincji Polskiej jako odpowiedzialnych za rozwój Apostolstwa w naszym kraju, zachowując dotychczasowe ustalenia ${ }^{27}$.

\section{MISJA APOSTOLSTWA}

Najważniejsze wiadomości na temat Apostolstwa Dobrej Śmierci zostały zawarte w statucie francuskim, który stał się statutem także filii polskiej ADS. Dzięki niemu można poznać misję, charakter i zasady funkcjonowania Stowarzyszenia, ponieważ zostały w nim jasno określone: cel i środki do jego osiągnięcia, warunki i stopnie przynależności, przywileje duchowe, rola i zadania zelatorów. Wszystkie te elementy zostaną teraz szczegółowo omówione.

Cel. Stowarzyszenie Matki Bożej Patronki Dobrej Śmierci stawia sobie za cel główny przekazywanie i podtrzymywanie w sercu jego członków chrześcijańskiej nadziei. Czyni to poprzez powierzanie ich opiece Matki Bożej i zachęcanie do życia zgodnego z Ewangelią. Skłania do wspólnoty modlitwy i poświęcenia, dzięki czemu wszyscy członkowie uczestniczą w bogactwie wzajemnie wypraszanych dóbr duchowych.

Środki do osiągnięcia wyznaczonego celu są następujące: 1) zachęcanie do zaufania Bogu, na wzór Chrystusa składającego swoje życie w ręce swego Ojca; 2) propagowanie nabożeństwa do Matki Bożej Bolesnej, wzywanej jako Matka Boża Patronka Dobrej Śmierci; 3) szczególna zachęta do stałej i żarliwej praktyki miłości Boga i bliźniego, która jest konkretną formą inaugurowania życia wiecznego już w doczesności; 4) wychowywanie do regularnego przystępowania do sakramentu pokuty i pojednania oraz do uczestniczenia w Eucharystii.

Warunki przynależności są tylko dwa: 1) dobrowolne wyrażenie zgody na przyjęcie do Stowarzyszenia; 2) dokonanie wpisu (imienia i nazwiska) do Księgi Stowarzyszenia przechowywanej w centrali Stowarzyszenia w Górce Klasztornej. Wpis jest ważny przez całe życie i nie musi być odnawiany. Nie zapisuje się do Stowarzyszenia osób zmarłych, jak i nie wykreśla się z Księgi Stowarzyszenia zmarłych członków. Wszystkich ogarnia się modlitwą ${ }^{28}$. Wpisowi do Stowarzyszenia nie towarzyszą żadne obowiązkowe opłaty.

Stopnie przynależności do Stowarzyszenia są trzy: 1 stopień - uzyskuje się jedynie na podstawie wpisu do Stowarzyszenia i jest równoznaczny ze

${ }^{27}$ Por. J.-C. Boulanger, List do ks. Prowincjała.

${ }^{28}$ Do Stowarzyszenia mogą zostać przyjęte także dzieci, które są w stanie świadomie wyrazić własną zgodę. Jako zwyczajną praktykę przyjęto przyjmowanie dzieci po I Komunii Świętej. 
świadomym i dobrowolnym oddaniem się pod opiekę Matki Bożej Patronki Dobrej Śmierci; 2 stopień - jest szczególnie proponowany członkom rodzin chrześcijańskich i wiąże się z codziennym odmawianiem trzech Zdrowaś Maryjo ... tak rano, jak i wieczorem, łącznie z wezwaniem: Matko Boża, Patronko Dobrej Śmierci - módl się za nami; Święty Józefie - módl się za nami; 3 stopień - zalecany dla osób pragnących pogłębiać życie w łasce. Polega na wykonywaniu zobowiązań 2. stopnia i dodatkowo, codziennego, wieczornego rachunku sumienia oraz comiesięcznego, krótkiego modlitewnego skupienia jako praktycznego przygotowywania się do śmierci. Na tym stopniu proponuje się przynajmniej raz w miesiącu przystępować do sakramentu pokuty i pojednania oraz przyjmować Komunię Świętą ${ }^{29}$.

Przywileje duchowe, jakimi cieszą się członkowie Stowarzyszenia, są dwojakiego rodzaju: 1) uczestnictwo w łaskach płynących z celebrowanych codziennie Mszy św. w intencji żywych i zmarłych członków Apostolstwa Dobrej Śmierci; 2) uczestniczenie w łaskach płynących z przyjmowania daru odpustu zupełnego, który członkowie Stowarzyszenia mogą upraszać pod zwykłymi warunkami w następujące dni:

- w dzień wstąpienia do Stowarzyszenia,

- 19 marca - Uroczystość św. Józefa,

- 31 maja - Święto Nawiedzenia Najświętszej Maryi Panny,

- 15 września - Wspomnienie Matki Bożej Bolesnej,

- 29 września - Święto Świętych Archaniołów,

- 1 października - Wspomnienie Świętej Teresy od Dzieciątka Jezus ${ }^{30}$.

Ponadto w Stowarzyszeniu szczególną rolę odgrywają zelatorzy i zelatorki. Są to osoby świeckie, które dobrowolnie decydują się na współpracę z odpowiedzialnymi za Apostolstwo kapłanami, aby rozpowszechniać je $\mathrm{w}$ parafiach, środowiskach pracy i w rodzinach oraz pomagać w realizowaniu zadań statutowych ADS. Zelatorzy i zelatorki wspomagają kapłanów w organizowaniu i prowadzeniu spotkań modlitewno-formacyjnych Stowarzyszenia, odwiedzaniu chorych i czuwaniu przy umierających. O ich szczególnej roli Pius XI pisał: „Chcemy zachęcić umiłowanych synów, jeśli tylko są ze stowarzyszenia, a szczególnie zelatorów, by pilnie doskonalili się w trosce o zbawienie swoje i innych. [...] Dlatego w sposób szczególny pragniemy wspomnianej pilnej gotowości zarówno towarzyszy, jak i zelato-

${ }^{29}$ Nie ma konieczności kolejnego „przechodzenia” stopni. Można od razu zapisać się na stopień 2. lub 3. Po zapisaniu się na niższy stopień można przejść na wyższy bez dokonywania formalnego zgłoszenia. Wystarczy samodzielne podjęcie duchowych zobowiązań kolejnego stopnia.

${ }^{30}$ Por. Reskrypt Penitencjarii Apostolskiej, Rzym 19.04.1994; cyt. za: J.-C. Boulanger, List do ks. Prowincjała. 
rów, by w jakikolwiek sposób uporali się ze zgubnym błędem, który sprawia, że - ze szkodą dla duszy - chorzy nie są wcześniej namaszczani świętym olejem aniżeli w obliczu nieuchronnej śmierci, gdy niemal całkowicie utracili zmysły. Albowiem, aby sakrament został ważnie i godziwie udzielony, nie jest konieczne, aby mająca nadejść śmierć już zagrażała, ale wystarczy roztropność i osąd o prawdopodobnym niebezpieczeństwie. Jeżeli zaś w takim stanie rzeczy powinno się go udzielić, w takiej sytuacji z pewnością można to zrobić i kto troszczyłby się o to, by został udzielony, ten nie tylko podąża za doktryną Matki Kościoła, lecz spełnia pobożnie i zbawiennie to, co najlepsze" ${ }^{31}$.

Na postawie zaprezentowanej charakterystyki Apostolstwa Dobrej Śmierci w oparciu o jego statut widać, iż jest to wspólnota modlitewna, której członkowie - tak duchowni jak i świeccy - starają się poprzez osobiste zaangażowanie duchowe i apostolskie wyjednać potrzebne łaski dla trzech grup ludzi. Dla wiernych katolików pragną wytrwania w łasce uświęcającej; dla obojętnych religijnie i grzeszących - łaski nawrócenia, a dla wszystkich - łaski dobrej śmierci.

Prawie sto lat temu papież Pius XI, kontynuując myśl swoich dwóch poprzedników na Stolicy Piotrowej, uznał Apostolstwo Dobrej Śmierci (Stowarzyszenie Matki Bożej Patronki Dobrej Śmierci) za apostolat: owocny, zbawienny, dynamiczny i szeroko propagowany ${ }^{32}$.

Praktycznym potwierdzeniem aktualności apeli, kierowanych przez papieży, jest współczesny rozwój działalności duszpasterskiej Apostolstwa, którego prezentacja wymaga osobnego studium. Obecnie, po latach pewnej stagnacji w czasach komunizmu, można znowu mówić o jego dynamicznej i owocnej obecności w Polsce i poza jej granicami. Zainteresowanie Stowarzyszeniem rośnie z roku na rok, o czym świadczy chociażby fakt powstawania nowych grup ADS w parafiach oraz systematycznie powiększająca się liczba członków Apostolstwa.

Jako duszpasterze Apostolstwa Dobrej Śmierci szczerze pragniemy wraz z członkami naszego Stowarzyszenia nadal głosić nadzieję życia wiecznego ludziom będącym na różnych etapach życia: zdrowym, chorym i umierającym. Pomagając im przygotować się do śmierci w taki sposób, aby można ją

\footnotetext{
${ }^{31}$ PIUS XI, [tłum. ks. M. Gubernat MSF].

32 Por. tamże.
} 
było nazwać naprawdę dobrą, ponieważ prowadzącą prosto w ramiona Boga, jako Misjonarze Świętej Rodziny kontynuujemy misję powierzoną przez Kościół założycielom Stowarzyszenia - Ojcom Najświętszej Maryi Panny z Tinchebray.

\section{BIBLIOGRAFIA}

Association de Notre-Dame de la Bonne-Mort. Notice Historique, Tinchebray 1963.

BENEDYKT XV, List apostolski Inter sodalicia, Rzym 31.05.1921, (AAS 18,181-185), wydanie internetowe: http://www.vatican.va/archive/aas/documents/AAS-10-1918-ocr.pdf (28.11.20 19).

Benedykt XV, List Peraccepta Nobis, Rzym 24.11.1914, (AAS 6, 693); wydanie internetowe: http://www.vatican.va/archive/aas/documents/AAS-06-1914-ocr.pdf (28.11.2019).

BENEDYKT XV, List apostolski Sodalitatem, Rzym 31.05.1921, (AAS 13,342-346), wydanie internetowe: http://www.vatican.va/archive/aas/documents/AAS-13-1921-ocr.pdf (28.11. 2019).

Boulanger J.-C., List do ks. Prowincjała Polskiej Prowincji Misjonarzy Świętej Rodziny ks. Włodzimierza Burzawy MSF, Sées 24.11.2004.

CzeKaŁA J., Wszystko zaczęto się od wypadku... czyli początki ADS w Polsce, „Nadzieja i Życie” 2017, nr 1, s. 4-5.

Dyrektorium Prowincjalne Polskiej Prowincji MSF, w: Konstytucje i Dyrektorium Generalne. Dyrektorium Prowincjalne Polskiej Prowincji, wyd. 3, Zgromadzenie Misjonarzy Świętej Rodziny, Poznań 2002.

Glemp J., Dekret N. 2150/87/PR, Gniezno 30.05.1987.

Kongregacja ds. Kultu Bożego i Dyscypliny Sakramentów, Dyrektorium o pobożności ludowej i liturgii. Zasady i wskazania, Pallottinum, Poznań 2003.

Moricová J., Matka Boża Siedmiobolesna - patronka Stowacji. Teologia i kult, (Mariologia w kontekście, t. 3), Redakcja Wydawnictw KUL, Lublin 2002.

MoszumańSKi K., Sanktuaria Matki Bożej Bolesnej w diecezji świdnickiej, w: Misericordia et veritas. Księga jubileuszowa dla uczczenia biskupa Ignacego Deca, t. 2: W darze, red. A. Tomko, PWT, Wrocław 2014, s. 433-452.

Muraro M.M., Pedico M.M., Addolorata, w: Mariologia, red. S. De Fiores, V. Ferrar Schiefer, S.M. Perrella, San Paolo, Cinisello Balsamo (Milano) 2009, s. 6-16.

Palmer P.F., The Purpose of Anointing the Sick. A Reappraisal, „Theological Studies” 1958, nr 19, s. 309-344.

PAPIESKa RADA DS. ŚwIECKICH, Dekret N. 535/04/S-61/B, Watykan 13.03.2004.

Pedico M.M., El culto de la Virgen de los Dolores desde 1848 a 1950 en la Orden de los Siervos de Maria, b.m.r., wydanie internetowe: http://servidimaria.net/sitoosm/es/historia/conguno /11.pdf (08.08.2019).

PIUS X, List Ubere cum fructu, Rzym 30.04.1911, (AAS 3,265-266); wydanie internetowe: http://www.vatican.va/archive/aas/documents/AAS-03-1911-ocr.pdf (28.11.2019).

PIUS XI, List apostolski Explorata res, Rzym 02.02.1923, (AAS 15,103-107), wydanie internetowe: http://www.vatican.va/archive/aas/documents/AAS-15-1923-ocr.pdf (28.11.2019).

Prevoteau F.J., Les Frères de Tinchebray (1850-1882), b.m.w., 2007; wydanie internetowe: http://www.lamennais.org/wp-content/uploads/2016/03/em36.pdf (06.09.2019). 
Reskrypt Penitencjarii Apostolskiej, Rzym 19.04.1994.

R. SARAh, N. DiAT, Wieczór się zbliża i dzień już się chyli, przeł. A. Kuryś, Wydawnictwo Sióstr Loretanek, Warszawa 2019.

Serra A., Maria presso la Croce. Solo l'Addolorata? Verso una rilettura dei contenuti di Giovanni 19,25-27, (Edizione Messaggero Padova, t. 12. Maria nella tradizione biblica 3/2), Messaggero di Sant'Antonio, Padova 2011.

SobCzyK A.J., KRUPA P.J, W kręgu duchowości świętorodzinnej, Bernardinum, Pelplin 2007.

Stowarzyszenie Matki Boskiej Patronki Dobrej Śmierci, Bernardinum, Górka Klasztorna 1996.

WoJtKowski J., Bolesna Matka Boża, I. Kult, Koronka, w: Encyklopedia Katolicka, t. 2, red. F. Gryglewicz, R. Łukaszyk, Z. Sułowski, Towarzystwo Naukowe KUL, Lublin 1976, k. 754-757.

\section{APOSTOLSTWO DOBREJ ŚMIERCI - HISTORIA I MISJA}

\section{STRESZCZENIE}

22 lipca 1908 roku papież Pius X ustanowił Stowarzyszenie Matki Bożej Patronki Dobrej Śmierci stowarzyszeniem uniwersalnym dla całego Kościoła. 30 maja 1987 roku Prymas Polski kard. Józef Glemp zatwierdził Polską Filię Stowarzyszenia z centralą w Sanktuarium Maryjnym w Górce Klasztornej, a tym samym zezwolił Misjonarzom Świętej Rodziny na prowadzenie tego dzieła. Celem Stowarzyszenia jest propagowanie modlitwy o dobrą śmierć i przygotowywanie do niej. Artykuł jest szczegółową prezentacją historii i misji Stowarzyszenia, które znane jest także jako Apostolstwo Dobrej Śmierci.

Słowa kluczowe: towarzyszyć; dobra śmierć; apostolstwo. 